\title{
SOME DEVELOPMENTAL STUDIES OF THE PHARYNX AND SOFT PALATE OF THE ONE HUMPED CAMEL (CAMELUS DROMEDARIUS)
}

\author{
Y. R. Wally
}

\begin{abstract}
The present study was carried out on 78 camel's fetuses having different measurements, collected from El-Basateen slaughter house in winter. The CRL ranged from $9 \mathrm{~cm}$ to $118 \mathrm{~cm}$.

Half of the specimens (of different CRL) were dissected laterally to determine the changes which occurred upon the pharyngeal diverticulum and atlanto-pharyngeal muscle.The rest of specimens (of different CRL) were sawed sagittally to determine and follow up the changes of the pharyngeal cavity and soft palate.

Externally, the dorsal wall of the pharynx presented a small thin walled median dorsal diverticulum which enlarged in size and divided into rostral and caudal compartments by the M.atlantopharyngeus.

Internally, the nasopharynx was divided by a small transverse fold into a rostral and a caudal compartment. The soft palate had a small dorsal elevation and a ventral diverticulum called dulla. .
\end{abstract}

Key words: Camel- Feoti- Pharynx -Soft palate.

\section{INTRODUCTION}

Camel's anatomy attracted the attention of many investigators due to the increase in using of such an animal in the field and in feeding. The importance of the pharynx as serving a dual function of feeding and respiration is a fundamental vertebrate characteristic (Graham, 2001). The anatomy of the camel's pharynx has been previously described by Hegazi (1945), Tayeb (1950), Ibrahim (1983), Smuts and Bezuidenhout (1987) and Wally (1989). 
On tracing the available literatures dealing with the developmental studies of the pharynx and soft palate in the domestic animals, no papers were found. For this reason, the present work was carried in order to give some detailed informations about the development of the pharynx and soft palate in the camel as an attempt to give more knowledge about that animal, which could be of benefit to Anatomists and Surgeons.

\section{MATERIAL AND METHOD}

The present study was carried out on 78 camel's fetuses having different measurements, collected from El-Basateen slaughter house in winter.

The fetuses were freshly measured from the vertex of the head along the back to the breech at the base of the tail (Knopse, 2002) to determine the CRL (crown rump length). The CRL ranged from $9 \mathrm{~cm}$ to $118 \mathrm{~cm}$.

The long CRL specimens were injected via the common carotid artery using formalin solution (10\% formalin, $4 \%$ phenol, $1 \%$ glycerin), followed by immersion in formalin solution for 3-4 days (Tomsett and Wakelly, 1965). The short CRL specimens were soaked in formalin solution or injected via the oral cavity with formalin. Half of the specimens (of different CRL) were dissected laterally to determine the changes which occurred upon the pharyngeal diverticulum and atlantopharyngeal muscle which were taken as a guide for grouping: The specimens were divided into three groups according to the CRL.Each group was carefully described.

Group I. includes 34 foeti ranged from 9-21 cm CRL.

Group II. Includes 28 foeti ranged from $22-53 \mathrm{~cm}$ CRL.

Group III. Includes 16 foeti ranged from $54-118 \mathrm{~cm}$ CRL. 
The rest of specimens (of different CRL) were sawed sagittally to determine and follow up the changes of the pharyngeal cavity and soft palate.

The caliber was used for measurements of the different parts of the pharyngeal cavity and soft palate.

Nomenclature used in this study was adopted according to Nomina Anatomica Vetrinaria 2005 (Electronic version).

\section{RESULTS}

\section{Group I:}

Externally, the dorsal wall of the pharynx presented a small thin walled median dorsal diverticulum (fig.2,3/A) extending from the roof of the nasopharynx toward the base of the cranium.

The fibers of atlantopharyngeal muscle (fig.3/B) could be seen in fetuses of $11 \mathrm{~cm} \mathrm{CRL}$ as fine thin muscle fibers directed rostro-ventrally on the lateral aspects of the pharyngeal diverticulum.

Internally, the pharyngeal cavity (fig.1) in this group showed a short funnel shaped appearance. It extended from the choanae rostrally up to the level of the atlas caudally. Its length ranging from $0.9 \mathrm{~cm}$ in $9 \mathrm{~cm}$ CRL fetus to $3.5 \mathrm{~cm}$ in $21 \mathrm{~cm}$ CRL fetus.

The pharyngeal cavity was divided rostrally by the soft palate (fig.1/A) into Pars nasalis (fig.1/D) dorsally and Pars oralis (fig.1/C) ventrally. It measured about 0.4 to $1.3 \mathrm{~cm}$ in height in its rostral part which was reduced gradually to about 0.2 to $0.5 \mathrm{~cm}$ at the entrance of the oesophagus. 


\section{Pars oralis pharyngis (fig. 1/C):}

The oro-pharynx was short, extending from the glossopalatine fold to the base of the epiglottis. It has a thin and smooth mucous membrane. At the beginning of this group it measured about $0.5 \mathrm{~cm}$ in length which increased gradually reaching $1.7 \mathrm{~cm}$ in $21 \mathrm{~cm}$ CRL fetus. It communicated with the oral cavity through the narrow slit-like Isthmus faucium which was bounded by the dulaa (fig.1/B), dorsally and the root of the tongue (fig.1/I) ventrally.

\section{Pars nasalis pharyngis (fig.1/D):}

The nasopharynx appeared as narrow longitudinal passage which increased in width caudally. It extended from the choanae (fig.1/L) rostrally to the Isthmus pharyngis caudally. It ranged from $0.4 \mathrm{~cm}$ in $9 \mathrm{~cm}$ CRL fetus to $1.8 \mathrm{~cm}$. in length at $21 \mathrm{~cm}$ CRL fetus and about 0.6 to 1.2 $\mathrm{cm}$. in width along the group. It presented a thin, smooth mucous membrane.

\section{Pars laryngea pharyngis (fig.1/N):}

The laryngeo-pharynx, constituted the narrow short caudal part of the pharynx. It extended from the Isthmus pharyngis above and around the Aditus laryngis to be continued with the oesophagus on a level with the end of the atlas .It measured about 0.3 to $0.7 \mathrm{~cm}$ in length and about 0.3 to $0.5 \mathrm{~cm}$. in width.

\section{Palatum molle (fig. 1/A):}

The soft palate appeared as a muscluo-membranous fold projecting into the rostral portion of the pharynx, dividing it into a dorsally situated Pars nasalis and a ventrally situated Pars oralis. It continued caudoventrally to terminate in contact with the base of the epiglottis (fig1/E). Its length ranged from $0.7 \mathrm{~cm}$ at the beginning of this group which increased gradually reaching $2.4 \mathrm{~cm}$ in $21 \mathrm{~cm}$ CRL fetus. 
The palatine arch (fig.1/O) was concave and thin forming the rostral boundary of the intra-pharyngeal opening.lt lies in contact with the lingual surface of the epigllotis.It measured about 0.5 to $1.2 \mathrm{~cm}$. in width and about 0.2 to $0.4 \mathrm{~cm}$. in thickness.

From the middle of the ventral surface of the soft palate, the dulaa (fig.1/B) could be seen as a small thin walled ventral projection, lying in contact with the root of the tongue. At first, it measured about $0.3 \mathrm{~cm}$ in length at its base (attachment with the soft palate), which increased to $0.7 \mathrm{~cm}$ at the end of this group. At its apex (free ventral border) its length reduced reaching about 0.2 to $0.4 \mathrm{~cm}$.

\section{GROUP II:}

Externally, the pharyngeal diverticulum was enlarged in size and began to be divided into rostral and caudal compartments. The rostral compartment (fig.4/A) was the larger, ranging from $1 \mathrm{~cm}$ in length and $0.8 \mathrm{~cm}$ in height (at 22 $\mathrm{cm}$ CRLfetus) to $2.8 \mathrm{~cm}$ in length and about 1.7 $\mathrm{cm}$. in height (in 53 CRLfetus). The caudal compartment (fig.4/B) appeared as a small pyramid lying caudal to the insertion of the M.atlantopharyngeus. It was separated from the ventral arch of the atlas by connective tissue. It measured about 0.6 to $1.5 \mathrm{~cm}$. in length and from 0.4 to $0.9 \mathrm{~cm}$. in height along this group.

The M. atlantopharyngeus (fig.4/C) was enlarged and prolonged rostro-ventrally compressing the pharyngeal diverticulum dividing it into a rostral and a caudal compartment.

\section{Pars oralis pharyngis (fig.5/N):}

The mucous membrane of the oropharynx became thicker, showed a slight folded appearance especially on its caudal portion. It ranged from 1.9 to $6.3 \mathrm{~cm}$ in length and about 0.8 to $2.5 \mathrm{~cm}$ in width from the beginning to the end of the group. Short conical papillae could be seen especially on the floor as well as the lateral walls of the oropharynx. 


\section{Pars nasalis pharyngis (fig.5/L, M):}

A small transverse mucosal fold (fig.5/I) appeared ventral to the basilar part of the occipital bone. It projected downward about 0.6 to $1.5 \mathrm{~cm}$ dividing the nasopharynx into a rostral and a caudal compartment. The rostral compartment (fig.5/L) presented a triangular shape with its base caudally directed. In length, it measured about $1.2 \mathrm{~cm}$ in $22 \mathrm{~cm} \mathrm{CRL}$ fetus which increased gradually to $4.2 \mathrm{~cm}$ in $53 \mathrm{CRL} \mathrm{cm}$ fetuses. The pharyngeal orifice of the auditory tube could be seen as slit like at the caudal part of the lateral wall of the rostral compartment.

The caudal compartment (fig.5/M) appeared shorter than the proceeding one. It ranged from 0.6 (in $22 \mathrm{~cm}$ CRL fetus) to $1.9 \mathrm{~cm}$ (in $53 \mathrm{~cm}$ CRL fetus) in length. The mucous membrane appeared smooth along the rostral compartment of the nasopharynx but folded on the caudal one.

\section{Palatum molle (fig. 5/A):}

The soft palate was prolonged, traversing the pharyngeal surface of the epiglottis to terminate infront of the arytenoid cartilage. It ranged from 2.5 to $6.2 \mathrm{~cm}$ in length along this group. A small dorsal elevation (fig.5/C) appeared from the roof of the soft palate and expanded into the rostral part of the nasopharynx. Gradually, the dulaa (fig.5/B) expanded caudo-ventrally to occupy the space between the root of the tongue rostrally, lingual surface of the epiglottis caudally and the glossoepiglottic fold ventrally. It measured about 0.9 to $1.3 \mathrm{~cm}$ in length at its base and about 0.5 to $0.8 \mathrm{~cm}$ at its apex. 


\section{GROUP III:}

Externally, in this group, the pharynx presented two dorsal diverticulae (fig. 6/A, B) projecting from its roof. The dorsal relations of the pharynx in this stage were distinguished as the caudal part of the vomer (fig.8/Q), body of the sphenoid (fig.8/R) and the basilar part of the occipital bones (fig.8/S).

The rostral diverticulum (fig.6/A), presented a nearly quadrilateral shape with a thin mucosal wall. It ranged from $4.3 \mathrm{~cm}$ (in $54 \mathrm{~cm}$ CRL fetus) to $7.8 \mathrm{~cm}$ (in $118 \mathrm{~cm}$ CRL fetus). in length.

The caudal diverticulum (fig.6/B) became more prominent, separated from the cranial diverticulum by the ventral part of the $M$. atlantopharyngeus. It ranged from 2 to $3.6 \mathrm{~cm}$ in length.

The M. atlantopharyngeus (fig.6/C) enlarged, preceded in a rostroventral direction to be terminated at the mid-dorsal line of the pharyngeal roof between both dorsal diverticulae.

\section{Pars oralis pharyngis (fig. 8/G):}

The oropharynx was greatly enlarged (6.5 to $11.3 \mathrm{~cm}$ in length), its mucous membrane became thicker and showed a slight folded appearance especially on its caudal portion.

The palatine tonsil (7/A) could be seen as a low rounded to elongated group of lymphoid follicles with several minute orifices. It measured about 0.4 to $1 \mathrm{~cm}$. in length. It was located on the caudal part of the lateral wall of the oropharynx. 


\section{Pars nasalis pharyngis (fig. 8/ H, J):}

The pharyngeal orifice of the auditory tube (fig.9/G) elongated, reaching about $1.1 \mathrm{~cm}$ in length in $118 \mathrm{~cm}$ CRL fetus. It covered medially by a thin mucosal fold.

The transverse fold (fig.8/I) projected more downward, appeared to be formed by fibers of the atlantopharyngeal muscle surrounded by mucous membrane on either side. Its length increased from 0.6 to1. $1 \mathrm{~cm}$ at the end of this group.

The rostral compartment (fig.8/H) presented a triangular shape with its base caudally directed. It extended from the end of the horizontal part of the palatine bone up to the middle of the basilar part of the occipital bon (fig.8/S). It ranged between 4.2 to $8.4 \mathrm{~cm}$. in length and about 0.4 to $0.8 \mathrm{~cm}$ in height rostrally which increased to about $1.5 \mathrm{~cm}$. caudally.

The caudal compartment (fig.8/J) appeared shorter and narrower than the proceeding one. It ranged from 1.9 to $3.9 \mathrm{~cm}$. in length and about 1.5 to $2.5 \mathrm{~cm}$. in height.

The pharyngeal tonsil (fig.9/D) appeared as a small scattered lymph follicle with clear orifices. It was situated on the caudal part of the lateral wall of the nasopharynx.It ranged from 0.2 to $0.4 \mathrm{~cm}$. in length.

\section{Palatum molle (fig. 8/A):}

The soft palate elongated, reaching the level of the corniculate cartilage. It ranged from $6.3 \mathrm{~cm}$ (in $54 \mathrm{~cm}$ fetus) to $11 \mathrm{~cm}$ (in $118 \mathrm{~cm}$ fetus) in length. It presented a clear dorsal elevation (fig.8/C) and a ventral dulla (fig.8/B). 


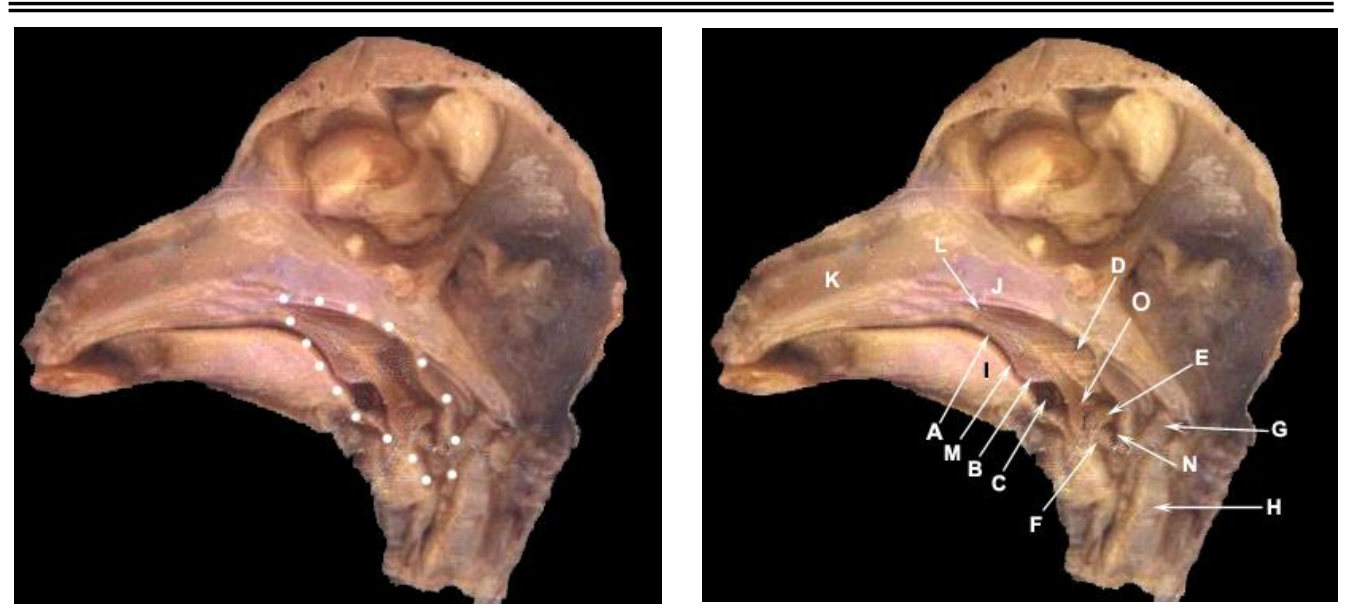

Fig. (1): A photograph of $9^{\text {th }} \mathrm{cm}$ C.R.L. Fetus showing the pharyngeal cavity (boundries of the pharyngeal cavity dotted white).
A- Palatum molle.
K- Septum nasi
F- Cartilago arytenoidea.
C- Pars oralis pharyngis.
M- Ismuth Faucium.
H- Axis.
E- Cartilago epiglottidis.
O- Arcus Palatinus.
J- Cartilagenous base of skull.
G- Atlas.
B- Dulaa.
L- Chonae.
I- Radix linguae.
D- Paris nasalis pharyngis.
N- Pars laryngea pharyngis.

Kafrelsheikh Vet. 1

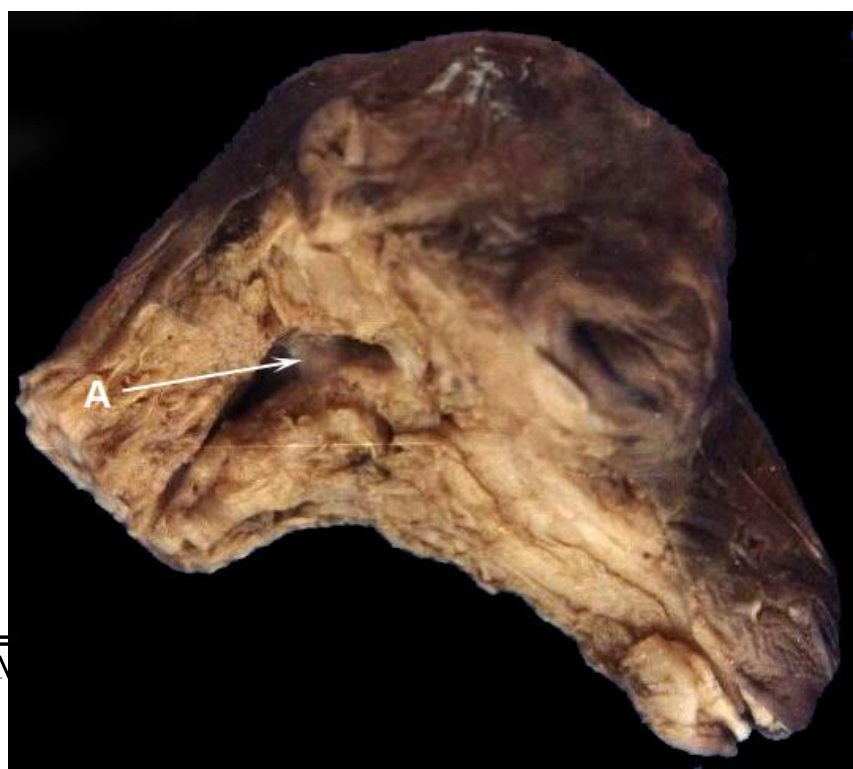


Fig. (2): A photograph of $14 \mathrm{~cm}$ C.R.L. Fetus showing the pharyngeal diverticulum.

A- Diverticulum Pharyngeum.

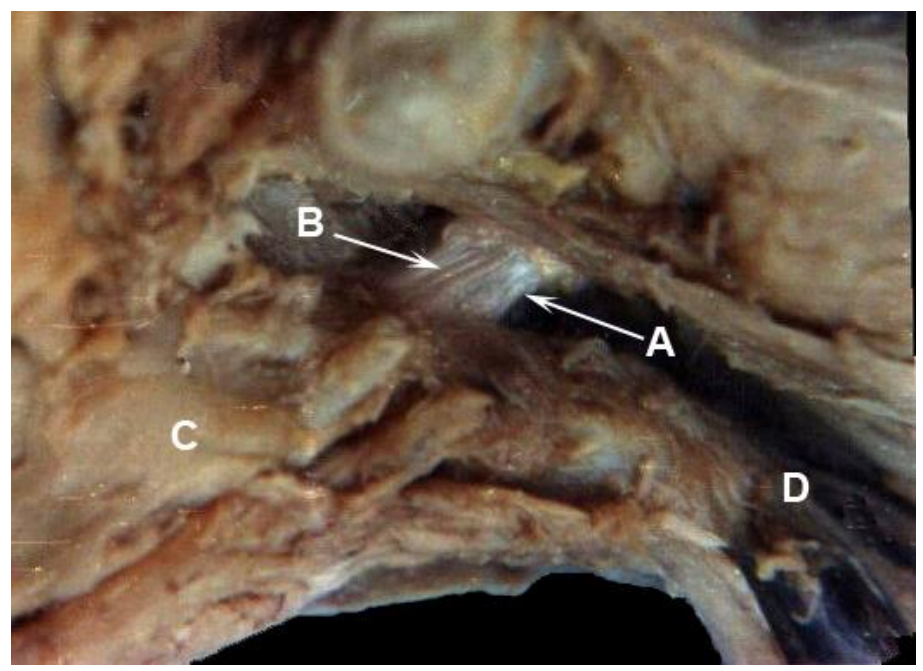

Fig. (3): A photograph of $21 \mathrm{~cm}$ C.R.L. Fetus showing the atlantopharyngeal muscle.
A- Diverticulum Pharyngeum.
C- Radix linguae.
B- M. atlantopharyngeus.
D- Oesophagus.

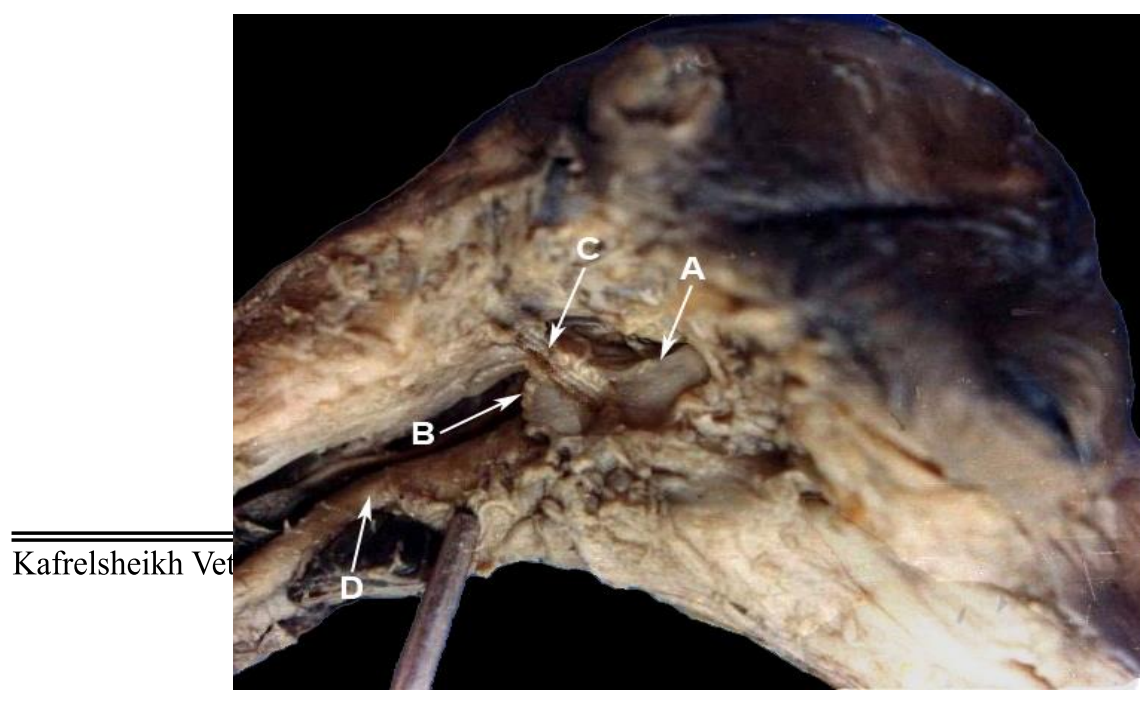


Fig. (4): A photograph of $29 \mathrm{~cm}$ C.R.L. fetus showing the pharyngeal diverticulae (Right side).
A- Diverticulum Pharyngeum cranialis.
C- M. atlantopharyngeus.
B- Diverticulum Pharyngeum caudalis.
D. Oesophagus.

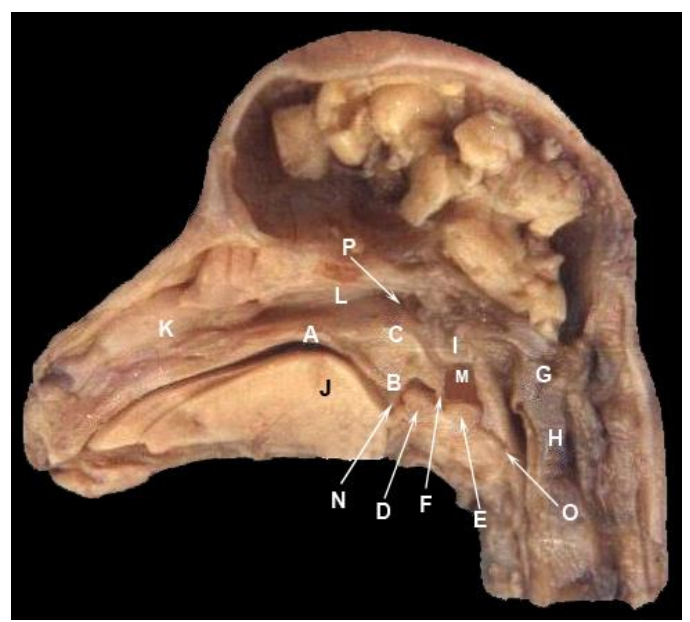

Fig. (5): A photograph of $31 \mathrm{~cm}$ C.R.L. fetus showing the morphological changes of the pharyngeal cavity.
A- Palatum molle.
F- Arcus palatinus.
H- Axis.
C- Plica dorsalis ad platum molle.
M- Pars caudalis ad pars naslis.
J- Radix linguae.
E- Cartilago arytenoidea.
O- Aditus Osephygeus.
L- Pars nasalis.
G- Atlas.
B- Dulaa.
N- Pars oralis pharyngis.
I- Plica transverses.
D- Cartilago epiglottidis.
P- Ostium pharyngeum tubae auditive.

K- Cavum nasalis.

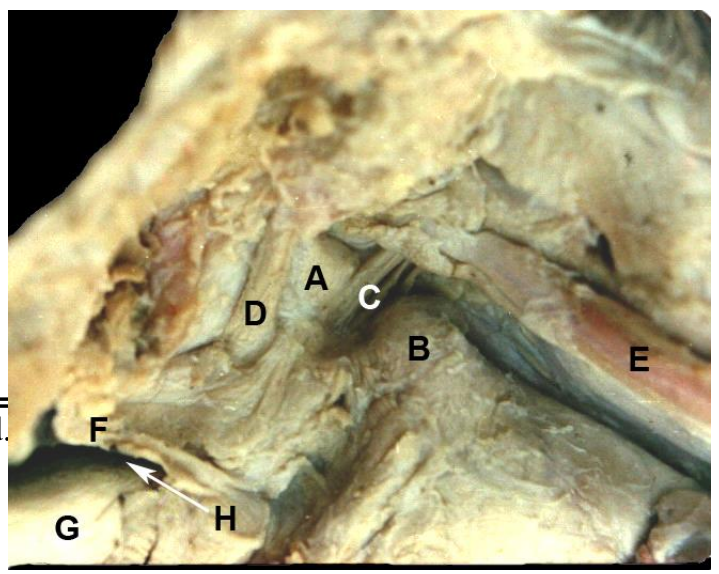


Fig. (6): A photograph of $52 \mathrm{~cm}$. C.R.L. fetus showing the pharyngeal diverticulum.
A- Diverticulum Pharyngeum cranialis.
D- M. Tensor velli palatine.
G- Glossa.
B- Diverticulum Pharyngeum caudalis.
E- M- Longus capitis.
H- Isthmus faucium.
C- M. atlantopharyngeus.
F- Plica glossopalatine.

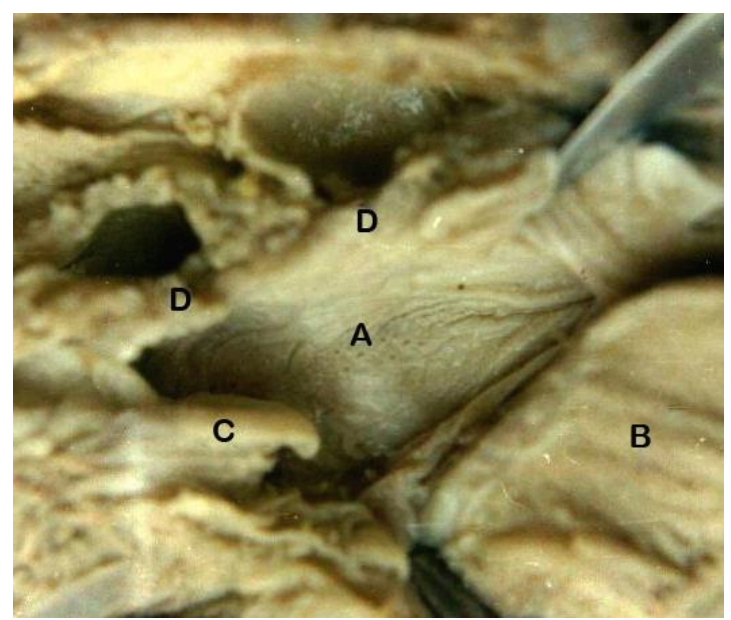

Fig. (7): A photograph of $58 \mathrm{~cm}$. C.R.L. fetus showing the palatine tonsil
A- Tonsilla palatine.
C- Cartilago epiglottidis.
B- Radix linguae.
D- Palatum molle.

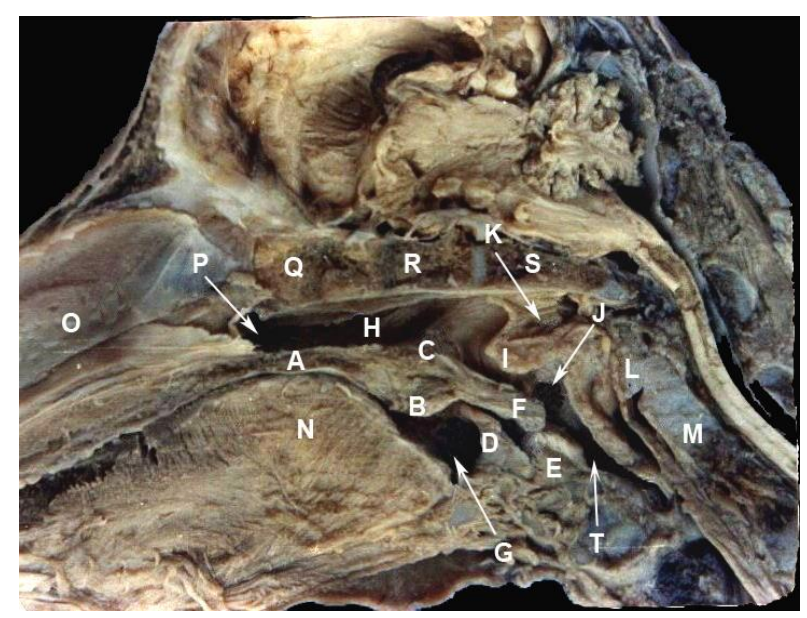

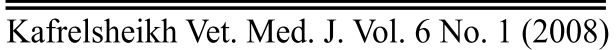


Fig. (8): A photograph of $64 \mathrm{~cm}$ C.R.L. fetus showing the morophological changes on the pharyngeal cavity.
A- Palatum molle.
H- Pars cranialis ad pars nasalis.
O. Septum nasi.
B- Dulaa.
I- Plica transverses.
P- Choanae.
C- Plica dorsalis ad platum molle.
J- Pars caudalis ad pars naslis.
Q- Vomer.
D- Cartilago epiglottidis.
K- M. atlantopharyngeus.
R-Sphenoid bone.
E- Cartilago arytenoidea.
L- Atlas.
S- Os occipitale (Pars Basilaris).
F- Arcus palatinus.
M- Axis.
T- Oesophagus.
G- Pars oralis.
N. Radix linguae.

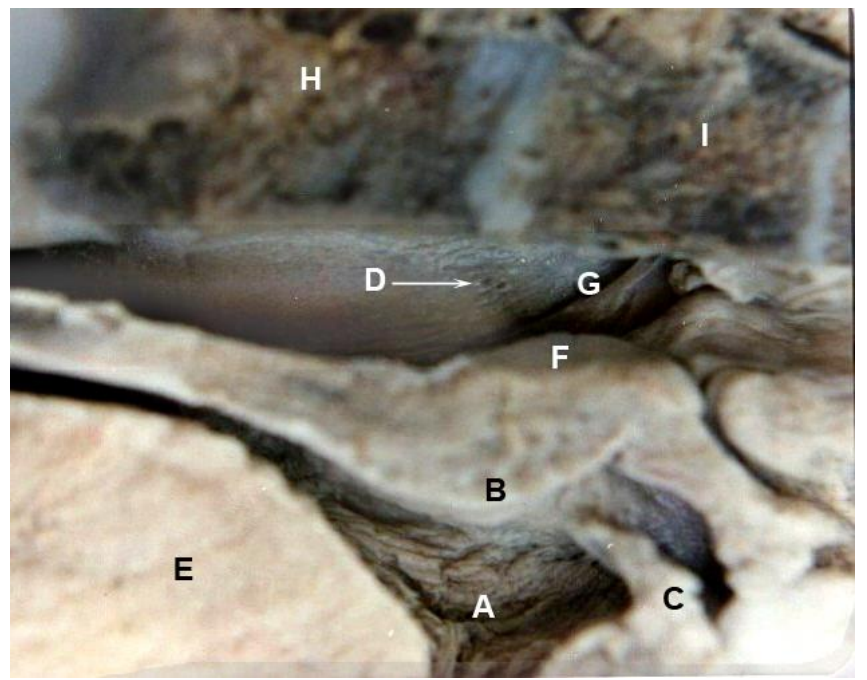

Fig. (9): A photograph of $88 \mathrm{~cm}$. C.R.L. fetus showing the pharyngeal tonsil.
A- Pars oralis.
D- Cartilago arytenoidea.
G- Ostium pharyngeum tubae auditive.
B- Dulaa.
E - Plica dorsalis ad palatum molle.
H- Sphenoid bone.
C- Cartilago epiglottidis.
F- Radix linguae.
I- Os occipitale (Pars Basilaris).

\section{DISCUSSION}

The present work depended on the measurement of the CRL in grouping and description of changes which occurred in the pharyngeal cavity and soft palate in feoti .This was in accordance with the statement of Eaton (1952) Bunger (1972) and Nelson and Cooper (1975) as there is no absolutely accurate method of estimating the age of an embryo or 
fetus from its length or weight and also the developmental formula has no practical use.

The study revealed that the pharynx extended from the choanae to the level of atlas, and then gradually it increased in length and extended caudoventrally up to the middle of the axis. Similar results were given by Ibrahim (1983) in the adult camel.

The study revealed that, the pharynx presented a small thin walled median dorsal diverticulum in $9 \mathrm{~cm} \mathrm{CRL}$. fetus extending from the roof of the nasopharynx toward the base of the cranium. That gradually enlarged and divided into two compartments by the growth of the atlantopharyngeal muscle. In the adult camel the pharynx was presented an irregular long funnel shaped with two dorsal diverticulae (Wally, 1989). In this respect Wilson (1984) and Smuts and Bezuidenhout (1987) reported that the pharynx was long and narrow without stating any results about the diverticulae.

The fibers of the atlantopharyngeal muscle could be seen at $11 \mathrm{~cm}$ CRL. Fetus, originated from the ventral surface of the atlanto-occipital joint capsule. Similar origin was recorded by Tayeb (1950) and Smuts and Bezuidenhout (1987) in the adult camel. The atlantopharyngeal muscle proceeded rostroventrally on the lateral surface of the pharyngeal diverticulum, gradually dividing it into rostral and caudal compartments. In the adult, it was placed between both compartments of the pharyngeal diverticulum (Wally, 1989).

In the dissected specimens, the oropharynx appeared as short narrow with thin and smooth mucous membrane, by the end of the 
gestation period the mucous membrane became thick, folded with short conical papillae. It ranged from 0.3 to $10.3 \mathrm{~cm}$ in length. In this respect (Ibrahim, 1983) mentioned that the oropharynx was long, wide and dilatable, with about $20 \mathrm{~cm}$ in average length in the adult camel.

In the present work, the palatine tonsils could be seen at $58 \mathrm{~cm}$ CRL .fetus as low rounded group of lymphoid follicles with several minute orifices on the caudal part of the lateral wall of the oropharynx. In the adult it was composed of numerous irregular follicles with different shapes as observed by Wally (1989).

The nasophrynex is appeared as a cone with a rostrally directed apex. Gradually a small transverse fold projecting downward, dividing the nasophrynx into a rostral and a caudal compartments. Such fold was observed by Arnautovic and Abd-EL Magid (1974) and Ibrahim (1983) as projecting from the roof of the nasopharynx, dividing it into two compartments in the adult camel. The current study, observed that the transverse fold contained the fibers of the atlantopharyngeal muscle.

Concerning the pharyngeal orifice of the auditory tube it could be seen as a slit like at the dorsolateral wall of the rostral compartment of the nasopharynx. Similar situation was reported by Smuts and Bezuidenhout (1987) in the adult camel. It was covered by a thin mucosal fold simulating that observed by Hegazi (1945) in the adult camel.

The pharyngeal tonsil could be seen as small rounded follicles with clear orifices infront of the tubal opening. In the adult it was represented by numerous scattered irregular lymph nodules along the dorsolateral wall of the nasopharynx (Wally, 1989). 
The current study observed that the soft palate began from the end of the hard palate; it continued caudoventrally to terminate in contact with the base of the epiglottis. Gradually, it prolonged traversing the pharyngeal surface of the epiglottis to terminate in contact with the dorsal surface of the arytenoids cartilage. Such result was in agreement with that recorded by Smuts and Bezuidenhout (1987) in the adult camel.

The dorsal surface of the soft palate gave rise to a small dorsal elevation projected into the rostral compartment of the nasopharynx. This is in accordance with the observation of Arnautovic and Abd-EL Magid(1974)in the adult camel.In the present work, the dulaa appeared as a small ventral projection of the soft palate. It expanded caudovenytrally to occupy the space between the root of the tongue and lingual surface of the epiglottis. In the adult camel, Leese (1927), Droandi (1936), Hegazi (1945) and Ibrahim (1983) agreed that the soft palate had an oroventral diverticulum called dulaa. In this respect Smuts and Bezuidenhout (1987) added that it was better developed in males than females. Wally (1989) measured it as to be $15-20 \mathrm{~cm}$ in male and $8-10 \mathrm{~cm}$ in female. On the other hand, Lesbre (1903) reported that the dulaa was absent in the double humped camel.

\section{REFERENCES}

- Arnautovic, I. and A. M. Abdel-Magid (1974): Anatomy and mechanism of distention of the dulaa of one-humped camel. Acta. Anat. 88: 115-124. 
- Bunger, I. (1972): Beitrag Zur Altersbesimmung Von Feten des deutschan Schwarrbunten Rindes insbesonere auf Grund Von Längenmessungen. Vet. Med. Diss. Hannover.

- Droandi, I. (1936): IL Camelo. Instituto Agricolo Coloniale Italiano XIV Firenze.

- Eaton, O. N. (1952): Weight and Length measurements of fetuses of Karakul sheep and goats. Growth 16, 175-187.

- Graham, A., (2001): The development and evolution of the pharyngeal arches. J. Anat. 199. pp. 133-141.

- Hegazi, M. A. H. (1945): Anatomy of the digestive system of the camel. M. V. Sc. Thesis. Cairo Univ.

- Ibrahim, I. A. A. (1983): Some anatomical studies on systema digestorium of the Camelus dromearius. Ph. D. Thesis. Assiut Univ.

- Knospe, C., (2002): Periods and stages of the prenatal development of the domestic cat. Anat. Histol. Embryol. 31, 37-51.

- Leese, A. S. (1927): A trearise on the one humped camel in health and disease. Hyanes and Son, Maiden Lane, Stawford, Lincolnshire.

- Lesbre, M. F. X. (1903): Recherches anatomiques sur les camldes. Archivesdue Musee D' Histoir Natureiles, Lyon.

- Nelson, N. S., and J. Cooper (1975): The growing conceptus of the domestic cat.. J. Anat. 85, 431-434.

- Nomina Anatomica Vetrinaria (2005): Electronic version. Prepared by the international committee on Veterinary Gross Anatomical Nomenclature and authorized by the eighteen ed. General Assembly of the word Assciation Zurich and I thoeo, New York. 
- Smuts, M. M. S. and A. J. Bezuidenhout (1987): Anatomy of the dromedary. Clarendon Press. Oxford.

- Tayeb, M. A. F. (1950): The pharyngeal cavity of the camel. Brit. Vet. J. Vol. 166: 29-31.

- Tomsett, D. H. and C. W. Wakeley (1965): Anatomical Techniques. $1^{\text {st }}$ Edition. E \& Living Stone Ltd. Edinburgh and London.

- Wally, Y. R. (1989): Some anatomical studies on the pharynx of the one humped Camel (Camelus dromedaries) in comparison with that of Ruminant animals. Ph. D. Thesis. Cairo Univ.

- Wilson, R. T. (1984): The camel $1^{\text {st }}$ ed. Longman London and New York.

بعض الدراسات الجنينية للبلعوم و الحنك الرخو للجمل وحيد السنام (دوميداري جمل) باسسر والهي

أجري البحث علي عدد 78 من أجنة الجمال جمعت من مجزر البساتين اثثاء الثتاء تراوحت اطوالها من 9 سم الي 118 سم و نم قياس الطول من قمة الرأس حتي قاعدة الذيل. تم معالجة العينات بمحلول الفورمالين (10\% فورمالين و 4\% فينول و 1\% جليسرين) تم

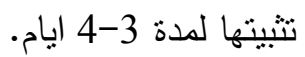
نم التنريح من الخارج بعد كسر عظمة الفك السفلى لتتبع نمو الردب البلعومى و كذلك العضلة البلعومية الفقهية (الحاملة). 
ثم عمل قطاعات طولية فى رؤؤس أجنة ذات أطوال مختلفة لدراسة التجويف البلعومى وكذلك دراسة الحنك الرخو ووصف التغيرات التى تطرأ عليها مع زيادة طول الجنين.

تم استخدام كل من العدات المكبرة لتحديد ووصف بعض التزاكيب و اتجاه الألياف العضلية. أوضحت الدراسة أن البلعوم الفمى بنقسم إلى جزئيين بواسطة طبة عرضية تحتوى علي ألباف العضلة

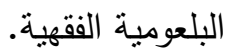
يتميز الحنك الرخو بوجود طية مخاطية صغيرة تمند من السطح الظهري الي الجزء الأول من البلعوم الأنفى و كذلك بوجود ردب بطنى (القلة) يمتد داخل البلعوم الفمى. 